論 文

\title{
室内環境の心理的側面からの分類に関する研究
}

\author{
専門会員 阪口 忠雄* 専門会員 江島 義道*
}

\section{A Study on the Psychological Classification of the Interior Environment}

\author{
Tadao Sakaguchi (Fellow Member) Yoshimichi Ejima (Fellow Member) \\ (Faculty of Engineering, Kyoto University)
}

\begin{abstract}
In case the structure of semantic space of the visual environments is analyzed in order to establish the evaluation method, it is necessary to examine the problem on concept by scale interaction.

Without this consideration, the evaluation method established according to semantic space will be applicable only to the limited field.

It is wasteful.

From this view-point, on experiment is carried out in order to get the fundamental knowledge about concept by scale interaction.

Eleven kinds of stimulus conditions such as a living room, a bank, a schoolroom, etc, are given as concept and their image profiles are measured by thirty four bi-polar adjective scales.

As a result of factor analysis, it is found that the mutual differences of image profiles may be explained by five common factors.

Eleven concepts are situated on the five scales according to estimated factor scores, and the relations among them are clarified.

\section{1. 序論}

従来の視環境設計においては，定量的測定が困難で西 るという理由から, 人間の心理的要素は軽視されてき た.しかし，近年になって人間の心理的，主観的要素が 物理的, 客観的要素より重要な意義をもつ場合があるこ とが指摘され，心理的要素の定量法拉よび評価法が重要 な問題としてとりあげられるようになった。

視環境の心理的要素の評価法の研究においてまず問題 となるのは，視環境の心理的属性にはどのような種類が あるかといら心理的属性の記述因子に関することであ る. 視環境空間に括淤る意味空間 (Semantie space)

の構造の解明は, 心理的属性の評価法の研究に之って重 要な問題となるのである.

視環境の心理的属性のような複雑な対象の因子を抽出 军る方法にはいるいるなものがあるが，これは大別して 二つに分けることができる，一つは心理的属性に対応す る尺度を判断の基準として，一対比較法によって一次元 尺度を構成し, 得られたいくつかの一次元尺度に因子分 析を施して多次元尺度を求めるもので方る。他の一つは Osgood らが意味研究に際して開発した Semantic Differential 法 (以下これを SD 法という) 用いる方法1) である.そしてすでに SD 法を使ったものとして，小木 曾, 乾の色彩効果の研究 ${ }^{2}$, 納谷, 浅野らの三色配色の配 色感情の研究 ${ }^{3)}$, 小木算, 市川のふんい気の研究4), 本城ら の照明器具評価の研究


しかしこのような SD 尺度ないしは，それに類似した 尺度を用いていろいろの対象の情緒的意味, または印象 を測定しようとするにあたって，または測定された結果 を評価汇利用しようとするにあたって，問題となるのは 対象一尺度間の交互作用(Concept by scale interaction) に関する問題である.すなわち判断の対象の種類が違え ば抽出される因子の種類, 数, 出現様相が異なり, また 同一の尺度であっても，その因子的意味が違ってくると いう問題である.

したがって, 視環境の心理的属性関する意味空間の 構造を解明するに際して，まず対象一尺度間の交互作用 の問題を検討することが必要之なる. もしこの検討が欠 けるならば，たと㐫る対象化対する意味構造が解明さ れ，これに基づいて心理的評価法が樹立されたとして も, その適用範囲怯狭い領域に限定されたものとなり, さだの多いものとなろう。

ところで，交互作用が対象の種類の違いによって生ず ると考兄るならば，交互作用の検討汇法次の二つの問題 が内包されていることになる。

(1) 対象の種類の相異は, 心理尺度上でどのように記 述され得るか

(2) 対象の種類によって，意味空間の構造はどのよう に相異するか

本稿ではまず，(1)の問題について次の二つの側面から 検討を加えた。一つは「各種視環境施設を分類するため の心理因子にはどのようなものがあるか」についてであ り，他の一つは「各視環境施設の心理尺度上での相対的 位置関係」についてである.具体的にいえば各種視環境 施設をとれぞれ概念として与え，そのイメージを測定す ることにより，各種視環境施設を分類するための心理因 子の抽出を行なった。 そして抽出された因子尺度上に各 対象を位置づけることにより, 各対象間の心理尺度上の 位置関係を求めた。

\section{2. 実験 \\ 2.1 目的}

実験の目的は, 視環境施設の相互の違いを表わす説明 因子を探り，それぞれの視環境施設の心理尺度上の位置 関係を明確化することである. 具体的汇峙次の 2 項目を 達成することである。

（1）刺激概念として，被験者に 11 種の視環境施設を 提示して 34 尺度のイメージ評定を求める. そして得ら れた測定結果汇因子分析を適用して，共通因子の抽出を 行なら.

（2）抽出された共通因子の因子評点をそれぞれの視環 境施設について求め, 施設相互の位置関係を明確にす る.

\section{2 方法}

\section{(1) 測 定 尺 度}

実験を行ならためには，末ず測定尺度をどのように選 定するかが重要な問題である・本実験では，すでに発表 されている SD 法汇関する文献と，筆者らが心理的属性 の評価法の研究の一部として行なった 46 対の両極尺度 による洋風応接間の SD 法の実験結果を参考化して測定 尺度を決定した. 種々の予備実験の後, 最終的に決定し た尺度は, 表 2 に示す 34 対の形容詞からなる両極尺度 である。

\section{（2）被 験 者}

測定を行なった被験者の構成は，表１亿示すとおり である・被験者の合計は 100 人である.

表 1 被験者構成

\begin{tabular}{|c|c|c|c|c|c|c|c|}
\hline 珄 & 22 末渵 & $22 \sim 25$ & $26 \sim 30$ & $31 \sim 35$ & $36 \sim 40$ & $41 \sim 50$ & $51 \sim 60$ \\
\hline 男 & 1 & 24 & 18 & 11 & 2 & 1 & 2 \\
\hline 交 & 1 & 25 & 13 & 0 & 0 & 1 & 1 \\
\hline
\end{tabular}

\section{(3) 刺 激 対 象}

刺激概念 (Concept) としての施設の選択は, 次の点 を留意して行なった。

(a)できるだけ視環境全体を代表し得るように選ぶ.

(b) 被験者のほとんどが，視環境設計と関係のない一 般人であるから特殊のものを避ける。

(c) 判断基準の個人差が大きいと思われるものを避计 る.

このようにして，最終的に選択した刺激概念としての 視環境施設は次の 11 種類である.

○居間 ○設計事務室 ○銀行 ○病院待合室 ○学 校の教室 ○ホテルロビー ○音楽ホールや劇場のロビ 一 ○ターミナル ○宝石店 ○レストラン ○百貨店 の日用品売場

\section{(4) 測 定 方 法}

測定は, 前述の 11 種の視環境施設の言語を刺激概念 として被験者に示して, 34 対の形容詞からなる両極尺度 のすべてについて, 11 段階汇評定させることによって行 なった，測定法一般のSD 测定において行なわれる絶対 評定ではなく, 11 種の施設を相互に比較して, 相対的に 評定させる方法を採用した。絶対評定法より弁別力の大 きい，比較判断を基礎とした測定法をとったので，評定 段階は, $\mathrm{SD}$ 法の測定でもっとも多く利用される 7 段階 にさらに 4 段階を增し，11段階とした。な打测定に際 し, 前もって被験者に与えたインストラクションは, 次 のと抢りである。

〔あなたは「環境のもつふんい気」について，どのよ らな傾向がもっとも好ましいと思いますか，解答例にな

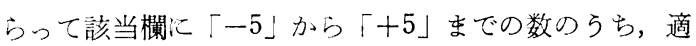


以上の分析過程を情報の入力, 出力関係を考虑してフ
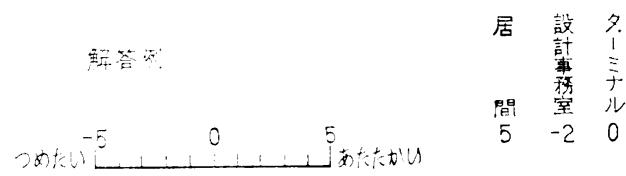

当と思われる数を選んで書き入れてください，解答例の 場合，居間の好ましいふんい気としては +5 の非常にあ たたかいふんい気が，設計事務室としては－2 のややっ めたいふんい気が，ターミナルのふんい気としては0の つめたい一あたたかいのどちらにも片寄らない中間のふ んい気が選ばれています，数字の選べる範囲は「一5」か ら「+5」までです. マイナスの数字が大きくなること は, 左側の形容詞のもつふんい気の程度が大きくなるこ とを, プラスの数字が大きくなることは, 右側の形容詞 のるつふんい気の程度が大きくなることを示します。ど ちらにも片寄らないと思う場合は 0 を選えでください。 同じ要領で，他の項目のそれぞれについてもあなたのイ メージを数字で記入してください. 記入の方法は一つの 尺度について11の施設全部を相対的に比較して評定し てください、な和測定結果俚個人の結果を問題にするも ので沈りりせんので，市なたの感じたるまを卒直化記 入してください.】

\section{3. 分析方 法}

測定結果の分析は次の手順で行なった。

（1）各尺度の平均值，標準偏差拉よび尺度間の相関倸 数の計算 計算 1

(2) 主成分分析法を繰り返し用いることにより因子数 の推定

計算 2

(3) Maxwell-Lawley の最尤推定法により直交軸の推 定 計算 3

(4) Kaiser の Varimax 法により直交回転し直交因 子の解积

計算 4

(5) Lederman の Shortened method により因子評 点の推定 計算 5

(6) 各施設ごとに因子評点の平均值の計算 計算 6

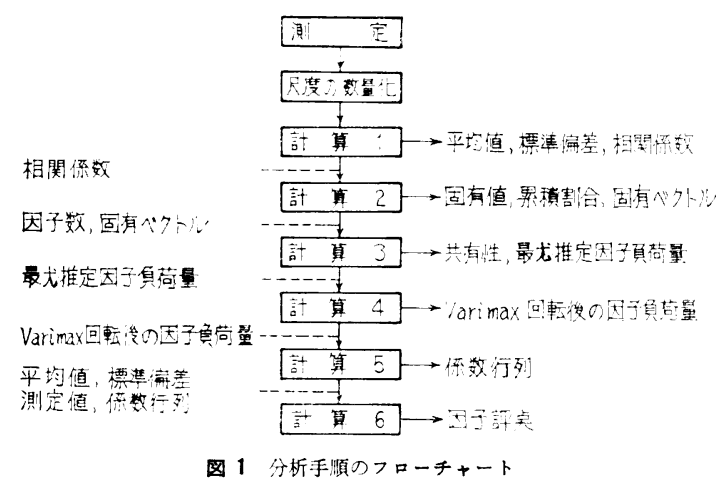

ローチャートに示すと図1のようになる.

\section{4. 分 析 結 果}

\section{（1）固有值と寄与率}

被験者 100 人, 各人の評定個数 $34 \times 11=374$ 合計 37,400 の評定值結果から 34 尺度間の相関係数を求め る. 次汇この相関係数を入力データとして主成分分析を 行なう. 主成分分析法の考方方をくり返し, 用いて成因分

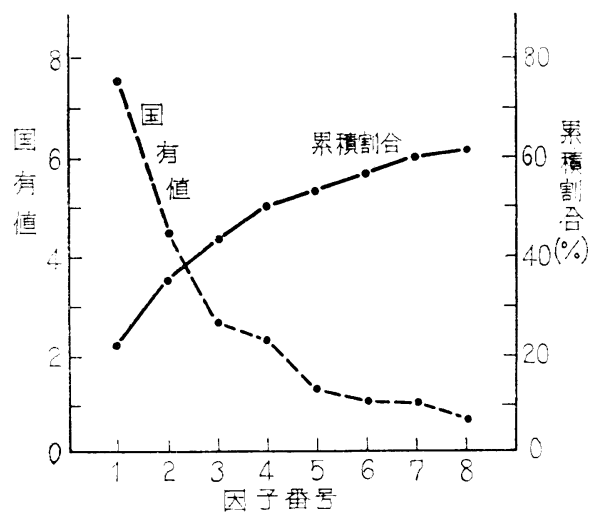

图 2 固有值と累皘割合

析を行ない，固有值と全分散化対する累積寄与率を求め ると図 2 が得られる。 これによると第 1 因子，第 2 因 子が大きく全体の変動の $21 \% ， 14 \%$ を説明する. 第 5 因子以後の因子はどれも小さく $3 \%$ 以下である.ここで は共通因子数として 6 因子を仮定寸る. 6 因子の累積割 合は $55 \%$ \%ある.

\section{（2）直交回転後の因子負荷量}

共通因子の数を 6 として最尤推定法により因子負荷量 を求める. 最尤推定計算の初期值としては成因分析結果 の固有ベクトルを標準化して用いた．このようにして求 めた因子軸汇は不定性があるので，Varimax 法により直 交回転を施ず. 直交回転後の因子負荷量を求める之表 2

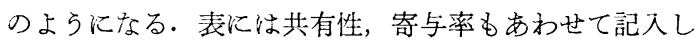
ている.

\section{（4）因子の解釈}

各因子の意味をわかりやすくするために，表 2 亿示し た因子負荷量をその絶対值の大きさにしたがって層別に 分類すると表 3 を得ることができる.この結果次のこ とが明らかとなる。

第 1 因子の示す内容はのんびりした，なごやかな，や わらかい，やさしい，にぶい，自由な，あたたかい，陽 気な，親し及やすい，感情的な，開放的な，軽やかなな ぞで表わされる．これらの尺度で表わされる情緹的意味 はのんびりした，なごやかな，やわらかい，やさしい， にぶい，開放的な，軽やかなで表わされる「なごやか さ」と，あたたかい，陽気な，親しみやすい，感情的な 
表 2 直交回転後の因子负茠肙

\begin{tabular}{|c|c|c|c|c|c|c|c|c|}
\hline 両極尺度 & 因子番号 & 1 & 2 & 3 & 4 & 5 & 6 & 共 有 性 \\
\hline のんびりした & はりつめた & -0.761 & 0.078 & -0.084 & -0.074 & -0.110 & -0.004 & 0.611 \\
\hline なごやかな & 敬粛な & -0.744 & 0.195 & 0.024 & 0.140 & -0.167 & -0.096 & 0.649 \\
\hline かたい & やわらかい & 0.726 & -0.185 & 0.090 & -0.050 & 0.125 & 0.187 & 0.623 \\
\hline こわい & やさしい & 0.585 & 0.038 & 0.110 & -0.112 & 0.209 & 0.259 & 0.480 \\
\hline ナるどい & にs゙い & 0.565 & -0.067 & -0.006 & 0.113 & 0.040 & -0.166 & 0.398 \\
\hline 束縛された & 自由な & 0.556 & -0.162 & 0.020 & -0.267 & 0.061 & 0.169 & 0.440 \\
\hline つめたい & あたたかい & 0.536 & -0.041 & 0.021 & -0.030 & 0.270 & 0.173 & 0.394 \\
\hline 親しみやすい & とっつきにくい & -0.468 & 0.031 & 0.042 & 0.230 & -0.340 & -0.290 & 0.475 \\
\hline 平静な & 刺激的疗 & 0.073 & -0.774 & -0.083 & -0.111 & -0.034 & -0.023 & 0.625 \\
\hline 落ち着いた & らわついた & 0.074 & -0.657 & -0.258 & -0.026 & 0.031 & -0.117 & 0.520 \\
\hline 静かな & にぎやかな & 0.187 & -0.641 & -0.317 & -0.216 & -0.008 & -0.043 & 0.595 \\
\hline 動的な & 静的な & -0.069 & 0.612 & 0.238 & 0.242 & 0.202 & 0.073 & 0.501 \\
\hline 派手な & 地味な & -0.191 & 0.579 & -0.270 & 0.142 & -0.156 & 0.150 & 0.513 \\
\hline すっきりした & ごちゃごちゃした & 0.148 & -0.542 & -0.328 & -0.044 & -0.150 & -0.102 & 0.458 \\
\hline 感情的な & 推知的な & -0.448 & 0.484 & -0.027 & -0.126 & 0.005 & 0.096 & 0.461 \\
\hline 変化にとんだ & 变化汇乏しい & -0.179 & 0.426 & -0.264 & 0.271 & -0.018 & 0.036 & 0.360 \\
\hline 清潔な & 不潔な & -0.001 & -0.392 & -0.353 & 0.251 & -0.277 & -0.032 & 0.042 \\
\hline 単純な & 複㗆な & -0.019 & -0.293 & 0.127 & 0.008 & -0.219 & -0.060 & 0.150 \\
\hline 票華な & そまつな & -0.089 & -0.015 & -0.701 & -0.038 & -0.088 & -0.060 & 0.513 \\
\hline 夢のような & 現実的灰 & -0.176 & 0.088 & -0.662 & -0.290 & 0.003 & 0.098 & 0.571 \\
\hline 上品な & 下品な & -0.006 & -0.260 & -0.609 & 0.044 & -0.071 & -0.257 & 0.512 \\
\hline 神秘的な & 世俗的な & 0.290 & -0.240 & -0.550 & -0.268 & -0.066 & 0.120 & 0.536 \\
\hline 威敩のある & らちっべらな & 0.232 & -0.383 & -0.524 & 0.018 & 0.048 & -0.220 & 0.527 \\
\hline 平济九な & 特艮のある & 0.078 & -0.162 & 0.485 & -0.084 & -0.178 & 0.206 & 0.350 \\
\hline 美しい & みにくい & -0.099 & -0.119 & -0.462 & 0.115 & -0.093 & -0.410 & 0.428 \\
\hline 活気のない & 活気のある & 0.157 & -0.196 & -0.128 & -0.689 & 0.029 & -0.053 & 0.558 \\
\hline 積極的な & 消極的な & -0.043 & 0.204 & 0.071 & 0.532 & 0.063 & -0.227 & 0.387 \\
\hline 阙放的な & 閉鎖的な & -0.392 & 0.276 & 0.080 & 0.477 & -0.173 & -0.127 & 0.511 \\
\hline 坛い & せまい & -0.116 & -0.029 & -0.106 & 0.453 & -0.089 & 0.040 & 0.241 \\
\hline 陽気な & 陰気な & -0.479 & 0.249 & -0.029 & 0.403 & -0.305 & 0.017 & 0.549 \\
\hline 明るい & 暗い & 0.017 & -0.148 & 0.108 & 0.362 & -0.429 & -0.025 & 0.350 \\
\hline はなやかな & しぶい & -0.146 & 0.471 & -0.039 & 0.090 & -0.427 & -0.000 & 0.436 \\
\hline 重みがある & 軽やかな & 0.311 & -0.319 & -0.214 & -0.070 & 0.349 & -0.017 & 0.372 \\
\hline たよりない & たのもしい & -0.156 & 0.256 & 0.138 & -0.162 & 0.020 & 0.511 & 0.398 \\
\hline \multicolumn{2}{|c|}{ Total variance } & $12.49 \%$ & $12.27 \%$ & $9.13 \%$ & $6.41 \%$ & $3.40 \%$ & $3.07 \%$ & $46.77 \%$ \\
\hline \multicolumn{2}{|c|}{ Common variance } & $26.71 \%$ & $26.24 \%$ & $19.52 \%$ & $13.71 \%$ & $7.27 \%$ & $6.56 \%$ & \\
\hline
\end{tabular}

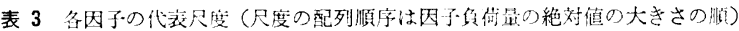

\begin{tabular}{|c|c|c|c|c|c|c|c|c|c|c|c|}
\hline \multirow[b]{2}{*}{0.7 以上 } & \multicolumn{2}{|c|}{1} & \multicolumn{2}{|r|}{2} & \multicolumn{2}{|c|}{3} & \multicolumn{2}{|c|}{4} & \multicolumn{2}{|c|}{5} & \multirow[t]{2}{*}{6} \\
\hline & $\begin{array}{l}\text { のんびりし } \\
\text { た } \\
\text { なごやかな } \\
\text { やわらか心 }\end{array}$ & $\begin{array}{l}\text { はりつめた } \\
\text { 政肃な } \\
\text { かたい }\end{array}$ & 平静な & 剌湤的な & 芜華な & そまつな & & & & & \\
\hline $0.7 \tilde{0}$ & $\begin{array}{l}\text { Pさしい } \\
\text { にふふい } \\
\text { 自由な } \\
\text { あたたかい }\end{array}$ & $\begin{array}{l}\text { こわい } \\
\text { するとい } \\
\text { 束縛された } \\
\text { つかたい }\end{array}$ & 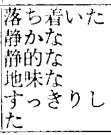 & 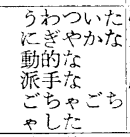 & $\begin{array}{l}\text { 夢のよ5な } \\
\text { 上品な } \\
\text { 神秘的な } \\
\text { 威蹻のある }\end{array}$ & 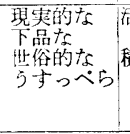 & $\begin{array}{l}\text { 活突のある } \\
\text { 積極的な }\end{array}$ & $\begin{array}{l}\text { 活支のな } \\
\text { 消極的な }\end{array}$ & & & Fのむしい カよりない \\
\hline $\begin{array}{c}0.5 \sim \\
0.3\end{array}$ & 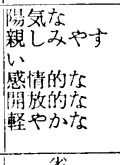 & 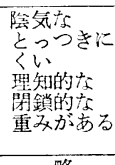 & 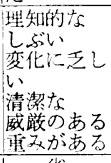 & 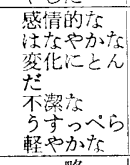 & 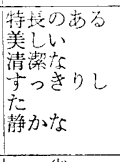 & 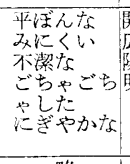 & $\begin{array}{l}\text { 開放的な } \\
\text { 鼠気な } \\
\text { 湤るい }\end{array}$ & 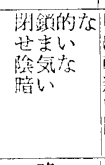 & 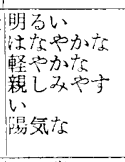 & 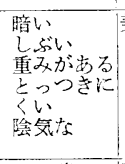 & 美しい \\
\hline $\begin{array}{l}0.3 \\
\text { 未満 }\end{array}$ & 省 & 略 & 省 & 略 & 省 & 略 & 省 & 略 & 省 & 格 & 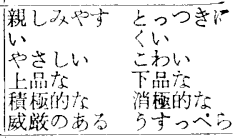 \\
\hline 萮 名 & 緊 㖘一 & 一 弛緩 & 落 ち & 着 き & 日常生活加 & らの距離感 & 活 & 性 & 明 & さ & たのむしさ \\
\hline 寄与率 & & $.49 \%$ & & $2.27 \%$ & & $.13 \%$ & & $41 \%$ & 3.4 & $19 \%$ & $3.07 \%$ \\
\hline
\end{tabular}

Vol. 57 No. 12 
で表わされる「あたたかさ」の二つにまとめることがで きる。

さらにこの二つの感情に共通なもの恃, 仕事の場面で 現われる緊張感からの開放感であり, 休息感あるいは逆 に緊張感で特徽づられる. 因子の命名は「緊張一弛 緩」とすることができる. 第 1 因子の寄与率は全体の変 動に対するものが $12.49 \%$ ，共通因子の変動に対するも のが $26.71 \%$ である.

第 2 因子の示す内容は平静な, 落ち着いた, 静かな, 静的な, 地味な, すっきりした, 理知的な, しぶい, 変 化に乏しい，清潔な，威㛜のある，重みがあるなどで表 わされる，これらの尺度で表わされる共通の感情は落ち 着きと重みで意味づけることがでさる，第 2 因子恪ち 着きの因子といえる. 第 2 因子の寄与率は全体の変動に 対するものが $12.27 \%$ であり, 共通因子の変動に対する ものが $26.24 \%$ である.

第 3 因子の示す内容は隹華な, 夢のような, 上品な, 神秘的な, 威敩のある, 特長のある, 美しい, 清潔な, すっさりした，静かななどで表わされる，これらの尺度 で表わされる感情は, 日常の生活から比較的離れた生活 空間，たとえばレストラン，ホテル，音楽ホール，劇場 などで比較的多く経験でさるものである，特に豪華な， 夢のような, 神秘的な, 威敩のあるで表わされる感情は 日常の生活空間ではほとんど経験することはできない。 したがって第 3 因子は，日常生活からの距離感と命名す ることがでさる、第 3 因子崎与率が全体の変動に対 するものが $9.13 \%$, 共通因子の変動に対するものが $19.52 \%$ である.

第 4 内子の示す内容は活気のある, 積極的な, 開放的 な，広い，陽気な，明るいなどで表わされる。このうち 活気のある，積極的なで表わされる尺度はこの因子に特 に強く現われ，因子負荷量がもっとも大きい，一力，開 放的な，陽気な，明るいで表わされる尺度はこの因子に だけ特に強く現われるものではなく，他の因子にも現わ れている・陽気な，明るいで表わされる尺度はむしろ他 の因子への寄与のほうが大きくなっている.

以上のことを考慮するなら，第 4 因子は活動性の因子 と命名することがでさる，第 4 因子の寄与率は全体の変 動に対するものが $6.41 \%$, 共通因子の変動に対応する ものが $13.71 \%$ である.

第 5 因子の示す内容明るい，はなやかな，軽やか な，親しみやすい，陽気ななどで表わされる。これらの 尺度で表わされる囚子は，明るさとはなやかさで意味づ 汀ることができる，第 5 因子は「明るい一暗い」の因子 負荷量がもっとも大さい点を考慮して, 明るさの因子と 命名する.

第 5 因子は, 寄与率が全体の変動に対するものが 3.40
\%, 共通因子の変動に対するものが $7.27 \%$ である.

第 6 因子の示す内容はたのもしい，美しい，親しみや すい, やさしい, 上品な, 積極的な, 威敩のあるなどで 表わされる.このらち親しみやすい, やさしい, 上品 な, 積極的な, 威戦のあるで表わされる尺度は因子負荷 量が 0.3 以下の尺度であり, 尺度間にほとんど共有性が 見られない。これらの尺度虫詰差に基ついて現われたも のであると考觉ることがでさる．第 6 因子の命名は因子 負荷量のもっとも高い尺度を考慮して「たのもしさ」の 因子とする，第 6 因子の寄与率は全体の変動化対するも のが $3.07 \%$, 共通因子の変動に対するものが $6.56 \%$ で ある・

以上, 因子分析で求めた 6 因子について因子軸の意味 を考えてきた，その結果次のことが明らかになった。

(a) 第 1 因子から第 5 因子まで忏，かなり明確に因子 の意義づけを行ならことができる。

(b) 第6 日子に関しては明確な解釈は困難である.

このことから, 本研究の因子数は 5 個とするのが妥当 と思われる。

次にこれらの 5 因子を Osgood の情緒的意味体系の 三次元と比較してみる. Osgood の第 1 因子は Evaluation，第 2 因子は Potency，第 3 因子は Activity とさ れている・本研究の第 1 因子は Potency に対応すると 思われる。第 2 因子は Activity と Potency の両方の意 味を共に持っているが，どちらかといえば Activity の ほうの色彩が濃いようである。第 3 因子は Osgood の Evaluation の因子に近いものである. 本研究の第4 因 子は Activity で意味づけられる. 第 5 因子は Potency によく対応する. 本研究の第 2 因子，第 4 因子を共に Activityとして意味づけるなら，両因子の違いはどのよ らに理解することができるだろらか。これは物に対する Activity と, 人に対する Activity の違いによるものと 思われる.

すなわち，第 2 因子が環境自体の持つActivityを 示すのに対して，第 4 因子性環境内で行動する人間の Activity を示すと考えることができる.

\section{(4) 視環境施設の心理尺度上での相対的位置関係}

因子の解釈の項では Varimax 回転後の因子負荷量に 基ついて，視環境施設の分類基準を示す心理因子の意味 を考えた。その結果 5 因子を抽出することができ，因子 はそれぞれ「緊張一弛緩」，「落ち着き」，「日常生活から の距離感」,「活動性」「明るさ」と意義つけられた。次 の問題として，いずれの施設が「緊張一弛緩」の因子の 評点が高いかなどといらことを求める必要がある。いい かえれば，各視環境施設をそれぞれの因子尺度上に配列 する必要がある.この問題は因子評点の推定によって解 決することができる. 本研究で行なった計算の手順は次 
のと打りである。

（a）表 2 に示した因子負荷量の結果を入力データとし $\tau$, Lederman $の$ Shortened method により因子評点 算出のための係数行列を計算する.

(b) (a)で求めた係数行列を用いて，被験者 100 人の 11 施設に関する合計 1,100 のセマンティックプロフィル結 果の因子評点を計算する。

(c) 1,100 個の因子評点結果を施設の種類別に 11 グ ループに分沪，グループごとの平均值を計算する.

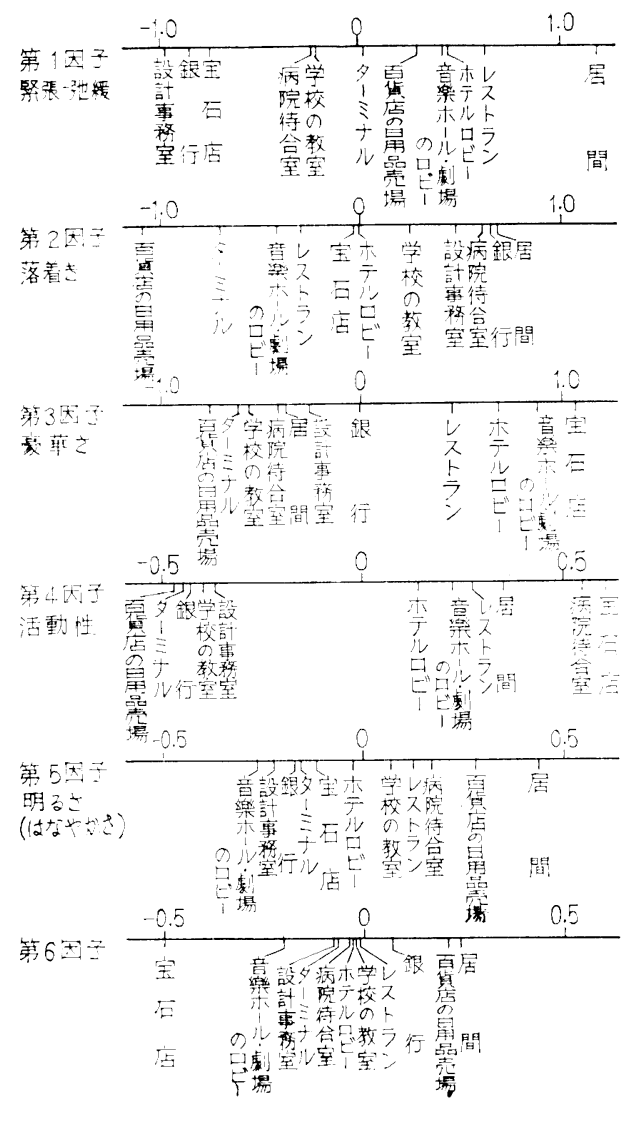

图 3 心理尺度上での相対的位瞋関保

計算の最終結果を因子ごとに一次元尺度上にプロット すると図 3 を得ることができる。この図を用いて，因 子の解积の項で行なった日子の意味づけに関して，その 妥当性を検討すると次のようになる。

第 1 冈子の正の側には大きいほうから

居間，レストラン，ホテルロビー，音楽ホールや劇場 のロビー, 百貨店の日用品売場, ターミナル

負の側には因子評点の絶対値の大きいほうから，

設計事務室, 銀行, 宝石店, 病院待合室, 学校の教室 が配列されている. 前者が私的生活をとりまくなごやか な，のんびりしたふんい気の環境であるのに対し，後者 ははりつめた（設計という仕事のもつ感じ），澉肃，理
性的な（貴重品を取り扱う仕事のもつ感じ）ふんい気を 持った環境である．前者怢息感という尺度でとらえる ことのできるものであり, 後者は緊張感といら尺度で理 解することができる. 第 1 因子の命名として「緊張一弛 緩」としたのは妥当であったと考劣られる。

第 2 因子の正の側には大きいほうから 居間, 銀行, 病院待合室, 設計事務室, 学校の教室 負の側に恃因子評点の絶対值の大きいほうから 百貨店の日用品売場, ターミナル, 音楽ホールや劇場 のロビー, レストラン, 宝石店, ホテルロビー が配置されている．前者が落ち着いた静かな環境である のに対し，後者はにぎやかな環境である．落ち着さとい らこの因子の命名は爱当であったと考党られる。

第 3 因子の正の側に快大汪らから

宝石店, 音楽ホールや劇場のロビー, ホテルロビー, レストラン

負の側には因子評点の絶対值の大きい泀らから

百貨店の日用品売場, ターミナル, 学校の教室, 病院 待合室，居間，設計事務室，銀行

が配置されている・前者は豪華な，夢のあるふんい気を もった日常の生活空間から離れた環境であり，その配置 順序は, 日常生活からの距離感といら尺度で理解するこ とがでさるが，後者は居間の位置がかなり中央に奇って いるので，その配置関係を日常生活からの距離感という 尺度で説明するに性多少の困難がある。これは恃しろ豪 華さといら尺度でとらえた汪らがより適切と思われる。

第 4 因子の正の側には大きい忹らから

宝石店, 病院待合室, 居間, レストラン, 音楽ホール や劇場のロビー，ホテルロビー

負の側には因子評点の絶対值の大きいほうから

百貨店の日用品売場, タ一ミナル，銀行，学校の教 室, 設計事務室

が配列されている、前者が行動性の乏しい動きの少ない 環境であるのに対し，後者は行動的な生き生さとした環 境である、第4 因子の命名として活動性としたが，これ は配置関係をよくいい表わしていると思われる，因子の 解釈の項で，第 2 因子亡第 4 因子の違い恃第 2 因子が環 境自体の Activity を示すのに対し，第 4 因子が環境内 の人間の Activity を示す点に㐌るとしたが，配列順序 は第 2 因子と第 4 因子の違いを端的溒わしている. 設 計事務室と学校の教室の他の施設に対する位置関係を雨 因子で比較することによって，新たに確認することがで きる。

第 5 因子の正の側には大きい注らから

居間，百貨店の日用品売場，病院待合室，レ天トラ ン，学校の教室

負の側には因子評点の絶対值の大きい汪らから

Vol. 57 No. 12 
音楽ホールや劇場の口ビー, 設計事務室, 銀行, ター ミナル, 宝石店, ホテルロビー

が配置されている.この配置関係から第 5 因子の命名因 子である「明るさ」という尺度を連想することは困難で ある.しかしこの「明るさ」を二つの意味, すなわち照 明的意味の明るさと, 怆かさの意味の明るさの複合 として意義つけると, 配置関係を明確に把握することが できる. 設計事務室, 銀行, ターミナル, 学校の教室, 居間の配列順序は, 照明的意味での明るさの順位関係を 示すものであり, 音楽ホールや劇場のロビ一, 宝石店, ホテルロビー, レストラン, 病院待合室, 百貨店の日用 品売場の配列順序は, はなやかさ感の大きさの順序を示 すものと理解することができる.

第 6 因子は大きい汪らから

居間, 百貨店の日用品売場, 銀行, レストラン, 学校 の教室, ホデルビー, 病院待合室, ターミナル, 設計 事務室，音楽ホールや劇場のロビー，宝石店

と配列されている.この配置関係は第 6 因子の代表尺度 であるたのもしさと美しさでは理解が困難である. 因子 評点も，汪とんど 0 近傍に集中していることから考えて も配置関係の有意な差は認められない。このことは第 6 因子が解釈困難であったことと符合する。

以上, 因子評点の位置関係から, 因子の解釈の項で行 なった命名因子の妥当性を検討した. その結果次のこと が明らかになった。

(a) 第 1 因子から第 5 因子までの因子の命名注注ば妥 当なものである.

(b) 第 3 因子㹥どちらかとい光ば，豪華さの因子と改 正したほらがよい。

(c) 第6因子㩆差の範囲にあると考えられる。

以上のことから逆に，各視環境施設の心理尺度上での 相対的位犆関係は，図 3 の第 6 日子を除いたもので示さ れると結論することができる。

\section{5. 結言}

視環境施設を心理的側面から分類する基準は何である かを見出すために，11種の視罣境施設を刺激概念とし
て，そのイメージプロフィルの違いを 34 個の雨極尺度 で測定した。そして得られた結果に因子分析を行なっ た. その結果, 分類基準の因子構造が 5 種の因子で構成 されること，5種の因子は「緊張一弛緩」，「落ち着き」，

「豪華さ」，「活動性」，「明るさ」で表わされることが明 らかになった。これらは種々の視環境施設の心理的側面 の比較を行ならとき，基礎資料として利用されらるもの である.

一方, 11 種の視環境施設は抽出された 5 個の因子の因 子評点を求めることによって, 心理尺度上での相対的位 置関係を明らかにした. この相対的位置関係に関する知 見は，これら施設の心理的側面の意義を検討するときに 役だつものと思われる.

対象一尺度間の交互作用をより直接的に知るために は, 問題(2)の「対象の種類によってどのように意味構造 が相異するか」について，さらに検討を加光なければな らないが，これは今後に残された課題である。

な新本研究の計算は, すべて京都大学大型計算機セン ターFACOM 230-60を使用した。

\section{参 考 文 献}

(1) C. E. Osgood, G. J. Suci and P. H. Tannenbaum : "The Measurement Meaning" Urbama, Univi. of Illinois Press (1957)

(2) 小木筸, 乾: “Semantic Differential (意味徴分) 法による建物の色彩効果の测定”建築学会論報 63 (1961) 105 113

（3）納谷ほか：“三色配色の Semantic Differential 法による感情分析” 電試裹報 31 (昭42) 1153, 32 (昭43) 195，221，33 (昭44) 261

(4) 小木既, 市川: 雾围気に関する研究, 建築学会論 報号外 9 (昭40) 406, 10 (昭41) 488，489，10 (昭42) 612，613，10 (昭43) 95，8 (昭44) 119

(5) 本城, 嶋田，占田：“住宅照明評価の表現語” 照 43連大 96

（6）浅野：“因子分析通詮”（昭46） （受付1973年 3 月16日） 